\title{
Factor Influencing Resiliency of Efficacy Diabetes Mellitus Patients
}

\author{
Nian Afrian Nuari ${ }^{*}$, Syiddatul Budury ${ }^{2}$, Theresia Anita Pramesti ${ }^{3}$ \\ ${ }^{1}$ STIKes Karya Husada Kediri, Kediri, Indonesia \\ ${ }^{2}$ STIKes Insan Se Agung Bangkalan, Bangkalan, Indonesia \\ ${ }^{3}$ STIKes Wira Medika Bali, Denpasar, Indonesia
}

\section{ABSTRACT}

Resiliency of efficacy means the ability of a person to rise from adversity that occurs in the problems that occur in his life especially if the patient Diabetes Mellitus who must maintain blood sugar levels for life so that no complications occur. The goal of this research is to analyze the factors related to resiliency of efficacy Diabetes Mellitus Patient's. The design of this study was explanatory with cross sectional approach. Sampling technique used purposive sampling got 100 respondents. Data collected by using questionnaire and analyzed with multiple linear regression $(\alpha=0.05)$. The results show that the majority of respondents Diabetes mellitus obtained that $31 \%$ of respondents have aged 60 to 70 years and has female gender of $65 \%$. This results acquired long suffering Diabetes Mellitus at most for 3-5 years. Respondents get information about Diabetes Mellitus disease as much as $44 \%$. For adherence to the medication as much as $54 \%$ have good adherence to treatment. While in the management of Diabetes mellitus dietary, consider half of respondents have diet according to Diabetes Mellitus. Based on the results as well as $52 \%$ have good adherence to activity management. The majority of respondents Diabetes mellitus captures high resiliency of efficacy. The multiple linear regression test analysis obtained there are influence of resiliency of efficacy with gender, education information about diabetes, long suffering diabetes mellitus, medication obedience, dietary adherence and activity adherence in Diabetes Mellitus Patients. The Resiliency of efficacy Diabetes mellitus needs to be improved by providing support to patients who can do family and community, so that patients are able to achieve a good quality of life.

KEYWORDS: resiliency, efficacy, factor, Diabetes Mellitus.

\section{INTRODUCTION}

Diabetes Mellitus patients need a high commitment to the disease because they have to maintain blood sugar levels to remain stable. This resulted in Diabetes Mellitus patients falling on conditions that make him must continue to maintain blood sugar so that it can become a burden in his life. This triggers the patient to experience psychological burdens other than the patient having to take medication for his illness. Psychological problems in Diabetes Mellitus patients can exacerbate metabolic disorders either directly through hormonal stress or indirectly through poor compliance. This condition needs to be done effective handling so that patients are able to perform the management of DM disease to prevent the occurrence of complications [1].

Based on the results of Basic Health Research 2013 mentioned an increase in prevalence in patients with Diabetes Mellitus who obtained the number of patients from the proportion of Diabetes Mellitus 5,7\% to $6,8 \%[2]$. Riskesdas reported that people with diabetes mellitus in East Java province as much as 2,1\% . Data from Riskesdas East Java, Diabetes Mellitus ranked 6th with 5.8\% in rural areas. Based on preliminary study on Kediri districts that have Diabetes Mellitus disease in 2016 as much as 16760 and 2017 until August as much as 2923.

Resiliency is needed by the individual for his ability to survive and rise again so that he can feel happy again after going through unpleasant issues in his life. Resiliency of efficacy is needed by individuals in adapting to the problems of disease to become a better individual in order to manage the disease Diabetes Mellitus. Based on Nuari, management of Diabetes Mellitus is to encourage patients to take greater responsibility for their care, and to perform self-care[3]. Patients suffering from Diabetes Mellitus disease have a great responsibility to regulate their behavior to always control their blood sugar.

Resilience is influenced by many factors. In conducting education to the patient, the nurse must pay attention to the physical and psychological aspects of the patient. Psychological support to these patients is very important in forming self-resiliency in solving problems. The nurse must be able to mediate the patient's condition by balancing the 
physical condition and psychological condition of the patient[4].

In the management of Diabetes mellitus there are several focus that must be implemented include the treatment, diet, physical activity, and blood glucose examination periodically. This must be done by diabetes mellitus patient during his life. Therefore it is necessary to analyze the resilience of efficacy of patients with diabetes Mellitus has a relationship with adherence in the management of Diabetes mellitus. This research aims to identify factors affecting the resilience of efficacy in Diabetes Mellitus in Kediri.

\section{RESEARCH METHODS}

The design this research was explanatory design with cross sectional approach. The population in this study were Diabetes Mellitus Type II patients without complications of diseases such as kidney failure and heart failure. Sample in this research was part patient of Diabetes Mellitus Type II by using purposive sampling with 100 respondents in Kediri. The dependent variables is resilience of efficacy. While the independent variables in this study are gender, education information diabetes mellitus, long suffering diabetes mellitus, medication obedience, dietary adherence and activity adherence. Research instruments for independent and dependent variables using questionnaires. Data collection was conducted at 2017 in Kediri. Data were analyzed with multiple linear regression test $(\alpha=0.05)$.

\section{RESULTS}

Table 1. Analysis of Variable

\begin{tabular}{|c|c|c|c|}
\hline Variable & Characteristic & $\mathbf{N}$ & $\%$ \\
\hline \multirow[t]{5}{*}{ Age } & $30-40$ & 6 & 6 \\
\hline & $41-50$ & 25 & 25 \\
\hline & $51-60$ & 27 & 27 \\
\hline & $60-70$ & 31 & 31 \\
\hline & $>70$ & 11 & 11 \\
\hline \multirow[t]{2}{*}{ Gender } & Male & 35 & 35 \\
\hline & Female & 65 & 65 \\
\hline \multirow{5}{*}{$\begin{array}{l}\text { Long Suffering Diabetes } \\
\text { Mellitus }\end{array}$} & $1-3$ years & 50 & 50 \\
\hline & $3-5$ years & 23 & 23 \\
\hline & $5-8$ years & 22 & 22 \\
\hline & $8-11$ years & 5 & 5 \\
\hline & $>\quad 11$ years & 0 & 0 \\
\hline \multirow{2}{*}{$\begin{array}{c}\text { Education } \\
\text { Information about DM }\end{array}$} & Ever & 44 & 44 \\
\hline & Never & 56 & 56 \\
\hline \multirow[t]{2}{*}{ Medication Obidience } & Obidience & 54 & 54 \\
\hline & Not Obidience & 46 & 46 \\
\hline \multirow[t]{2}{*}{ Dietary Adherence } & Adherence & 50 & 50 \\
\hline & Not Adherence & 50 & 50 \\
\hline \multirow[t]{2}{*}{ Activity Adherence } & Adherence & 52 & 52 \\
\hline & Not Adherence & 48 & 48 \\
\hline \multirow[t]{2}{*}{ Resiliency of Efficacy } & High & 51 & 51 \\
\hline & Low & 49 & 49 \\
\hline
\end{tabular}

Source: data analysis, 2017

Based on the above data obtained that 31 people (31\%) of respondents have aged 60 to 70 years, and the majority of respondents Diabetes mellitus has female gender of 65 respondents. Based on the above results obtained long suffered DM at most for 3-5 years. Respondents get information about Diabetes Mellitus disease as much as $44 \%$. For adherence to the treatment of Diabetes mellitus disease as much as $54 \%$ have good adherence to treatment. 
For adherence to the diet obtained half of respondents to diet according to Diabetes Mellitus patients. Based on the results also obtained as much as $52 \%$ have good adherence to management activities. Resiliency of efficacy Diabetes Mellitus Patients obtained 51 respondents have high resiliency.

Table 2. Summary Data Analysis

\begin{tabular}{|c|c|c|c|c|}
\hline $\mathbf{R}$ & R square & $\begin{array}{l}\text { Adjusted } \\
\text { R Square }\end{array}$ & Standard of error & Score Durbin-Watson \\
\hline $.738^{\mathrm{a}}$ & .544 & .515 & .35006 & 2.067 \\
\hline
\end{tabular}

Table 3. Summary Model Data Annova

\begin{tabular}{|lccccc|}
\hline Model & Sum of Square & $\begin{array}{l}\text { Freedom of } \\
\text { Square }\end{array}$ & Average & F count & Significant value degree \\
\hline $\begin{array}{l}\text { 1 Regression } \\
\text { Residual }\end{array}$ & 13.594 & 6 & 2,266 & 18.488 & $.000^{\mathrm{b}}$ \\
Total & 11.396 & 94 & .123 & & \\
\hline
\end{tabular}

Based on the result, dependent variable is resiliency of efficacy. The predictor variable is gender, education information diabetes mellitus, long suffering diabetes mellitus, medication obedience, dietary adherence and activity adherence. Based on Durbin-Watson score can be concluded this research suitable with multiple linear regression model. The data above it can be seen that the significance value of 0.000 is lower than the alpha of 0.05 , it can be concluded there are influence in this model.

Table 4. Data Analysis

\begin{tabular}{|l|c|}
\hline \multicolumn{1}{|c|}{ Model } & Significant value \\
\hline Constant & 0.047 \\
\hline Gender & 0.016 \\
\hline Education information Diabetes Mellitus & 0.000 \\
\hline Long Suffering & 0.035 \\
\hline Medication Obidience & 0.027 \\
\hline Dietary Adherence & 0.018 \\
\hline Actvity Adherence & 0.015 \\
\hline
\end{tabular}

The table above shows significance below 0.05 then this gender, education information diabetes mellitus, long suffering diabetes mellitus, medication obedience, dietary adherence and activity adherence have correlation with resiliency of efficacy in Diabetes Mellitus Patients.

\section{DISCUSSION}

\section{Analysis Between Age and Resiliency Of Efficacy In Diabetes Mellitus Patients}

The majority of Diabetes Mellitus patients are between 60 and 70 years old and $27 \%$ have 51 to 60 years of age. This is in accordance with research that Diabetes Mellitus disease suffered by many elderly people. Patients who have Diabetes mellitus have low sensitivity to insulin. With the passage of age can affect the sensitivity of insulin receptors to be less good. However, Nuari's (2015) studied that gender has no relationship to self-empowerment, in contrast to the resilience of efficacy[5].

\section{Analysis Between Gender and Resiliency Of Efficacy In Diabetes Mellitus Patients}

Based on the research found that as many as 35 women respondents have a high resiliency of efficacy. This is an important note for nurses who will educate patients need to provide a psychological approach to provide support for better patient resilience. Psychological approach is very important to improve patient confidence so that can adapt in managing the disease[4].

\section{Analysis Between Long Suffering Diabetes Mellitus and Resiliency Of Efficacy In Diabetes Mellitus Patients}

Based on the research found that as many as 11 respondents have high resilience of efficacy with the period of Diabetes disease mellitu mellitu for 2 years and 6 years. This suggests that long suffering also contributes to the resilience level of Diabetes Mellitus patients. Long suffering Diabetes can be the benchmark of a person whether 
able to adapt to the illness experienced.

\section{Analysis Between Education Information about Diabetes Mellitus and Resiliency Of Efficacy In Diabetes Mellitus Patients}

Based on the data of 39 respondents have received educational information about Diabetes mellitus disease. It is supported that the education strategy to Diabetes Mellitus patient can improve patient understanding about the management of the disease[6]. Patients who have a good intellectual ability to understand something will affect the ability of individual acceptance. Understanding of the disease Diabetes mellitus can as mediation in improving the component of resilience[7].

\section{Analysis Between Medication Obedience and Resiliency Of Efficacy In Diabetes Mellitus Patients}

Based on this research, it is found that the majority of patients have good adherence to treatment. The results of the study were 37 respondents who had high resilience and had good adherence to treatment. This is in accordance with the intervention done to improve patient resilience resulting in the patient's blood sugar level to be controlled[8]. This is also similar to Park's (2010) study which states that self efficacy of patients with diabetes mellitus also has an effect on adherence to treatment. The higher the self efficacy the more obedient the patient to the management of treatment[9].

The results also found that patients who have good medication adherence also have good knowledge. This is suitable with Omar's study (2014) that patients who have a good cognitive understanding of the treatment of Diabetes Mellitus disease have a high degree of adherence to the treatment of the disease [10].

\section{Analysis Between Dietary Adherence and Resiliency Of Efficacy In Diabetes Mellitus Patients}

Based on the data found that as many as 38 patients who have high resiliency have adherence to diet.

Diet is important in the management of Diabetes mellitus. Through good diet management able to stabilize the patient's blood sugar levels. Respondents with high resilience of efficacy are able to manage the diet in accordance with the recommended portion. This is in accordance with research Ganiyu (2013) that the cause of diet adherence due to the lack of psychological support so that caused resiliency of patients to be low[11].

\section{Analysis Between Activity Adherence and Resiliency Of Efficacy In Diabetes Mellitus Patients}

Based on the data found that as many as 38 patients who have high resiliency have adherence to the implementation of regularly activities. Physical activity done regularly can improve blood sugar control. Patients who have high resiliency will be free from stress so that the desire to perform physical activities for the better. This is in line with Qiu research (2012) that improving self efficacy and psychological support from families can support Diabetes Mellitus patients to perform continuous physical activity[12]. Physical activity is done regularly also can reduce the risk of Diabetes Mellitus disease, so that physical activity can be used as a preventive risk of Diabetes Mellitus disease [13] .

\section{CONCLUSION}

The results show that the majority of respondents Diabetes mellitus obtained that respondents have aged 60 to 70 years and has female gender, long suffering Diabetes Mellitus at most for 3-5 years and respondents ever get information about diabetes mellitus disease. For adherence to the medication as much as $54 \%$ have good adherence to treatment. While in the management of Diabetes mellitus diet, consider half of respondents to diet according to Diabetes Mellitus and 52\% have good adherence to activity management. There are influence of resiliency of efficacy with gender, education information about diabetes, long suffering diabetes mellitus, medication obedience, dietary adherence and activity adherence in Diabetes Mellitus Patients.

\section{REFERENCES}

1. American Diabetes Association. Diagnosis and Classification of Diabetes Mellitus. Diabetes Care [Internet]. 2011;34(Supplement_1):S62-9. 
http://www.pubmedcentral.nih.gov/articlerender.fcgi?artid=3006051\&tool=pmcentrez\&rendertype=abstract $\% 5$ Cnhttp://www.ncbi.nlm.nih.gov/pubmed/9118500\%0Ahttp://care.diabetesjournals.org/cgi/doi/10.2337/dc11 S062

2. Badan Penelitian dan Pengembangan Kesehatan. Riset Kesehatan Dasar (RISKESDAS) 2013. Lap Nas 2013. $2013 ; 1-384$.

3. Nuari NA. Pengembangan Model Peningkatan Pemberdayaan Diri dan Kualitas Hidup Pasien Diabetes Mellitus Tipe 2. J Ners Lentera. 2016;4(2):152-65.

4. Bradshaw BG, Richardson GE, Kulkarni K. Thriving with diabetes: An introduction to the resiliency approach for diabetes educators. Diabetes Educ. 2007;33(4):643-9.

5. Nuari NA. Analisis Korelasi Personal Factor, Perceived Benefit Dan Perceived Barrier Dengan Pemberdayaan Diri Pasien Diabetes Mellitus Tipe Ii Berbasis Teori Health. J Ilmu Kesehat Gaster. 2014;XI(2).

6. Nuari NA. Strategi Manajemen Edukasi Pasien Diabetes Mellitus. 1st ed. Yogyakarta: Penerbit Deepublish; 2017. 178-181 p.

7. Perfect MM, Jaramillo E. Relations between resiliency, diabetes-related quality of life, and disease markers to school-related outcomes in adolescents with diabetes. Sch Psychol Q. 2012;27(1):29-40.

8. Pesantes MA, Lazo-Porras M, Abu Dabrh AM, Ávila-Ramírez JR, Caycho M, Villamonte GY, et al. Resilience in Vulnerable Populations With Type 2 Diabetes Mellitus and Hypertension: A Systematic Review and Metaanalysis. Can J Cardiol. 2015;31(9):1180-8. Available from: http://www.ncbi.nlm.nih.gov/pubmed/26239007

9. Park K-A, Kim J-G, Kim B-W, Kam S, Kim K-Y, Ha S-W, et al. Factors that Affect Medication Adherence in Elderly Patients with Diabetes Mellitus. Korean Diabetes J [Internet]. 2010;34(1):55. Available from: https://synapse.koreamed.org/DOIx.php?id=10.4093/kdj.2010.34.1.55

10. Omar MS, San KLAI. Diabetes knowledge and medication adherence among geriatric patient with type 2 diabetes mellitus. Int J Pharm Pharm Sci. 2014;6(3):4-7.

11. Ganiyu AB, Mabuza LH, Malete NH, Govender I, Ogunbanjo GA. Non-adherence to diet and exercise recommendations amongst patients with type 2 diabetes mellitus attending extension II clinic in Botswana. African J Prim Heal Care Fam Med. 2013;5(1).

12. Qiu S-H, Sun Z-L, Cai X, Liu L, Yang B. Improving patients' adherence to physical activity in diabetes mellitus: a review. Diabetes Metab J [Internet]. 2012;36(1):1-5. Available from: http://www.pubmedcentral.nih.gov/articlerender.fcgi?artid=3283821\&tool=pmcentrez\&rendertype=abstract

13. Gill JMR, Cooper AR. Physical activity and prevention of type 2 diabetes mellitus. Sports Med. 2008;38(10):807-24. Available from: http://www.ncbi.nlm.nih.gov/pubmed/18803434 